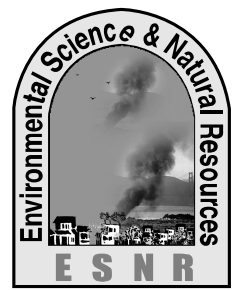

J. Environ. Sci. \& Natural Resources, 5(1): 141-150, 2012

ISSN 1999-7361

\title{
Seed Germination and Seedling Growth of Two Vegetables in Responses to Aqueous Extract of Four Herbal Plant Leaves
}

\author{
B. Roy ${ }^{1}$, B. C. Sarker ${ }^{2}$, M. R. Ali ${ }^{3}$, S. R. Das ${ }^{4}$ and M. A. S. Sayed ${ }^{5}$ \\ ${ }^{1,2,3}$ Department of Agricultural Chemistry, ${ }^{4,5}$ Department of Biochemisry and Molecular Biology, \\ Hajee Mohammad Danesh Science and Technology University, Dinajpur
}

\begin{abstract}
An experiment was conducted on aqueous extracts of leaves of some herbal plants viz., Beleric myrobalan; bohera (Terminalia belirica), Chebulic myrobalan; horitoki (Terminalia chebula), Sweet basil; tulsi (Ocimum gratissmum) and arjunaa myrobalan; arjun (Terminalia arjuna) for investigating the presence of biologically active substance. The seeds of two vegetable crops such as, swamp cabbage (Impoea aquatica) and okra (Hibiscus esculentus) were tested for germination and seedling growth treating with aqueous extract of four herbal plant leaves. The chemical investigation on effective plant extract was also attempted. The aqueous extract of bohera leaves increased germination of seeds tested and enhanced the growth of shoot length and root length of swamp cabbage (Impoea aquatica) and okra (Hibiscus esculentus) whereas the aqueous extract of horitoki significantly reduced and delayed germination, growth of shoot length and root length of swamp cabbage seeds compared with control; water. The maximum germination was in okra and swamp cabbage seeds within 5 and 4.8 days respectively, treated with the leaves extract of bohera. Shoot lengths were 16.2 and $16.43 \mathrm{~cm}$ and root length were 8.74 and $8.91 \mathrm{~cm}$ for okra and swamp cabbage seedlings, respectively. The aqueous extract of horitoki showed the lowest rate and late germination at 6 and 5.8 days and minimum shoot lengths were 13.13 and $13.36 \mathrm{~cm}$, and root lengths were 5.91 and $6.08 \mathrm{~cm}$ for okra and swamp cabbage seedlings, respectively. The thin layer chromatography (TLC) examination of chloroform extract of bohera leaves showed four distinct compounds at Hexane: Ethyl acetate $(3: 1, \mathrm{v} / \mathrm{v})$ while horitoki leaves showed three distinct compounds at Hexane: Ethyl acetate $(5: 1, \mathrm{v} / \mathrm{v})$.
\end{abstract}

Key words: Aqueous extract, Germination, Seed, Vegetables

\section{Introduction}

The plants are a vast receiver of compounds with a wide range of biological activities. Most of them have effective medicinal values, growth regulatory, herbicidal and pesticidal effects and also toxic values. Bohera (Terminalia bellirica), Horitoki (Terminalia chebula), Arjun (Terminalia arjuna), Tulsi (Ocimum tenuiflorum), extracts are commonly used as plant growth regulator or plant growth inhibitor. The plant product includes oil, extracts, dried leaves, fruits, seeds, rhizomes etc. Only Bohera based growth regulator have been evaluated as growth regulator of cereals, vegetables, cotton etc. The strongest inhibitory effect of aqueous extracts from Terminalia chebula on wheat seed germination, radical and plumule growth were reported by Tripathi et al. (1981). Tripathi et al. (1981) reported the strongest inhibitory effect of aqueous extracts of Eupatorium adenophorum on wheat seed germination, radical and plumule growth. Guenzi and Mc Calla (1962) showed that the water extract and the number of crop residues inhibited the germination growth of sorgam, corn and wheat in the laboratory experiment. They further reported that all residues contained water soluble substances that depressed the growth. An Experiment was conducted by B. Roy et al. (2006) on naturally occurring growth substances in aqueous extracts of some common weeds viz. Bothua (Chenopodium album), Bijli ghas (Striga densiflora), Shetdrone (Leucus aspera), Mutha (Cyperus rotundus), Chapra (Eleusine indica) and Khude anguli (Digitaria ischaemum) with the attempt for chemical investigation on effective extracts. Roy et al. (2006) reported that banana plant extracts exerted a significant inhibition on seed germination of lettuce and the degree of inhibition increase with the increase in concentration of extract. Hong Gao et al (2005) reported that Mammalian $\alpha$-glucosidase inhibitory activity by Terminalia chebula Retz. fruits were investigated. Regnault-Roger et al., (2005) reported the bioactivity of 22 essential oils from aromatic and medicinal plants was tested upon Acanthoscelides obtectus, Coleoptera; Bruchidae, a pest of kidney bean, Phaseolus vulgaris. Singh (2004) studied the effect of neem oil as surface protectant at $0,0.5,1.0$, 1.5 and $2.0 \%(\mathrm{w} / \mathrm{w}) 100 \mathrm{~g}$ of lentil seeds against the pulse beetle, Callosobruchus chinensis. Trematerra et al., (2002) tested fruits, extracts and metabolites of chilli, (C. annum) var. acuminatum, typical of the geographic areas of the molise region (central Italy) in an area for their attractive/repellent activity against adults of saw-toothed grain beetle ( Tribolium castaneum). Several investigators have reported that the effect of extracted primary and secondary metabolites from different weeds on germination, growth and development of various crops and some have insecticidal effects (Kohata et al., 2004). Islam (2002) found that plant material such as extract or powder of Bitter gourd, Karanja, Mehedi and Urmoi 
did not adversely affect seed germination. Reports are that some crop residues are known to have chemical (growth regulatory) as well as physical effect on the growth of several crops and weeds. Above information reported on germination, growth inhibitory or promoting influence, insecticidal activities as well as nutrient assimilation and other important biological activities of aqueous extracts of plants leaves residues during germination of different crops and also in different insect pests. But data are not available about the effect of different extracts of Bohera (Terminalia bellirica), Horitoki (Terminalia chebula), Arjun (Terminalia arjuna), Tulsi (Ocimum tenuiflorum) on germination, plumule and radicle growth of some selected vegetables crops. Study of aqueous extract of leaves of fruit plants is of practical significance in crop farming system for the germination of seed and also crop growth rate. In view of this, the present investigation was framed to investigate the effects of aqueous extract of Bohera (Terminalia bellirica), Horitoki (Terminalia chebula), Arjun (Terminalia arjuna) and Tulsi (Ocimum tenuiflorum) on germination and seedling growth of cabbage and lady's finger seeds and isolate the different bioactive compounds from the effective aqueous extract.

\section{Materials and Methods}

The experiment was conducted at research laboratory, Department of Agricultural Chemistry, Hajee Mohammad Danesh Science and Technology University, Dinajpur, Bangladesh, during June 2009June 2010 for the study of the effects of naturally produced growth substances in four herbal plant leaves viz. beleric myrobalan, chebulic myrobalan, sweet basil, arjuna myrobalan on country bean, lady's finger, swamp cabbage and yard long bean along with the attempt for chemical investigation on the effective leaf extract.

\section{Preparation of aqueous leaf extracts}

One hundred g (100 gm) of fresh and clean leaves was taken and cut into smaller pieces, it was then blended by using blender and was taken in a $500 \mathrm{ml}$ reagent bottle and $400 \mathrm{ml}$ of water was added to it. It was then kept for 72 hours at room temperature of $29 \pm 2^{\circ} \mathrm{C}$ and relative humidity of $85 \pm 5 \%$ with regular interval of stirring. After 72 hours the aqueous slurry was filtered through Whatmann filter paper No.1 and was taken in another $500 \mathrm{ml}$ bottle. The filtrates of individual plant extract were stored and used for treating the seeds of vegetable crops along with water as a control and other comprehensive study.

\section{Growth of vegetable crops}

Laboratory experiments in petridishes were done for swamp cabbage and lady's finger seeds for the observation of germination percentage; shoot growth and root growth, plant height etc. Clean petridishes with two sheets of filter papers were used. For the investigation of germination percentage, growth and development of vegetable seeds, $15 \mathrm{ml}$ of each aqueous extract was put in each petridish. In control, only distilled water was used and amount of distilled water was also same. Then twenty five (25) seeds of each vegetable crop were kept in each petridish and each treatment was replicated three times. The petridishes were kept in natural diffused light under laboratory conditions at $29 \pm 2^{\circ} \mathrm{c}$ temperature and relative humidity of $85 \pm 5 \%$ after placing. $5 \mathrm{ml}$ of water was used per day per petridish to keep constant moisture (Dubey, 1973). In control, only water was added if necessary per day per petridish. In this experiment, all subsequent observations were recorded and it was started from $16^{\text {th }}$ June, 2009. After setting the experiment, the germination percentages, shoot length, root length and completion of germination were recorded. Effects of different treatments on morphology of seedlings were also recorded. The collected data were analyzed statistically and the co-efficient of variance and means were compared by using Duncan's New Multiple Range Test (DMRT).

\section{Isolation of crude compounds from effective herbal plant using chloroform}

For isolation of crude compounds of the individual herbal plant, $100 \mathrm{~g}$ of the leaves of effective herbal plant's powder was taken in a $2.5 \mathrm{~L}$ reagent bottle and $250 \mathrm{ml}$ chloroform was added to the powder and it was then kept $72 \mathrm{~h}$ with regular interval of shaking. Then it was filtered by using Whatman filter paper No.1. The extract was collected in $500 \mathrm{ml}$ reagent bottle and $200 \mathrm{ml}$ of chloroform was added to the residue again, the reagent bottle was again kept for next $72 \mathrm{~h}$ with also regular interval of shaking. After $72 \mathrm{~h}$ it was filtered. The extracting processes were repeated for at least three times. The chloroform extracts of individual plant were combined together. The solvent was evaporated from the extract by using rotary film evaporator under reduced pressure. The different types of plant extracts made by chloroform were Horitoki (18.67 g) and Bohera (18.38 g). After evaporation the semisolid crude was stored in refrigerator at $0^{\circ} \mathrm{C}$ for further investigation.

\section{Isolation of crude compounds from individual herbal plant using ethyl-alcohol}

To the residue after chloroform extract, $200 \mathrm{ml}$ of ethyl-alcohol was added to it. It was kept for $72 \mathrm{~h}$ 
with several interval of shaking. After $72 \mathrm{~h}$ it was filtered by using Whatman filter paper No.1. The extract was collected in $500 \mathrm{ml}$ reagent bottle and 200 $\mathrm{ml}$ of ethyl-alcohol was added to the residue again, the reagent bottle was again kept for next $72 \mathrm{~h}$ with also regular interval of shaking. After $72 \mathrm{~h}$ it was then filtered. The process was also repeated for three times. The ethyl-alcohol extracts of individual plant were combined together. The solvent was evaporated by using rotary film evaporator under reduced pressure. The different types of plant extracts by using ethyl-alcohol were Horitoki (18.67 g) and Bohera (18.38 g). Both the extracts were also stored in refrigerator at $0^{\circ} \mathrm{C}$ for further investigation.

\section{Examination of crude extracts or crude compounds by $T L C$}

Thin Layer Chromatography (TLC) was applied to detect or identify the number of compounds or number of components present in a crude extracts. The $R_{f}$ value of each component was calculated by using this formula:

$\mathrm{R}_{\mathrm{f}}=\frac{\text { Distance traveled by the component }}{\text { Distance traveled by the solvent front }}$

TLC was prepared for the bohera leaves extract as the most potential and compounds were detected by using the solvent hexane and ethylacetate in the ratio of 5:1 (v/v).

\section{Results and Discussion}

Effect of aqueous extract of herbal leaves on swamp cabbage

\section{Germination}

The highest germination percentage was in 5.5 days found in seeds treated with water $\left(\mathrm{T}_{\mathrm{o}}\right)$ and statistically identical. Where the lowest germination percentage was in $T_{2}$ was found in seeds treated with Bohera. The second highest germination percentage was obtained from seeds treated with $\mathrm{T}_{1}$ (5.10 days), $\mathrm{T}_{3}$ (4.75days) and $\mathrm{T}_{4}$ (4.70 days) which were statistically similar. Similarly the highest seed germination percentage was obtained from the seeds treated with water but germination gradually increases in case of Bohera extract treated seed (Table 1).

\section{Shoot length}

Shoot length of swamp cabbage at different days after sowing influenced significantly by the effects of different fruit leaf extract (Table 2). At 10 Days after sowing (days) with the leaf extract of Bohera showed the highest shoot length $(15.63 \mathrm{~cm})$ whereas the lowest shoot length $(12.01 \mathrm{~cm})$ was recorded with Horitoki. Other treatments showed more or less similar statistical results at the same time. The highest shoot length of swamp cabbage seedling was found with Bohera extract $(22.05 \mathrm{~cm})$ at 15 days that was statistically different from others. And other treatments showed moderate results and leaf extract of Horitoki showed the lowest value $(18.22 \mathrm{~cm})$. At 20 days, 25 days and 30 days the highest shoot length was recorded in case of seed treated with Bohera leaf extract $(44.83 \mathrm{~cm}, 61.26 \mathrm{~cm}$ and $81.02 \mathrm{~cm}$, respectively). The other treatments perform moderately at different days after sowing (days). The increasing tendency of shoot length in aqueous extract of Arjun treated seedlings might be due to the presence of some growth regulatory materials. The highest shoot length of swamp cabbage seedling was found in Terminalia belirica aqueous extract possibly due to some growth regulator or other bioactive substances present in these species. 
Table 1. Effect of some herbal plant leaf extract on percent germination of swamp cabbage and lady's finger seeds

\begin{tabular}{|l|l|l|l|l|l|l|l|l|}
\hline \multirow{2}{*}{} & \multicolumn{5}{|c|}{ Treatment } & \multicolumn{5}{|c|}{ \% Germination cabbage } & \multicolumn{3}{c|}{ lady's finger } \\
\cline { 2 - 8 } & $\begin{array}{l}\text { Days to } \\
\text { first } \\
\text { germinatio } \\
\text { n }\end{array}$ & $\begin{array}{l}\text { Time to } \\
\text { 50\% } \\
\text { germination }\end{array}$ & Vigor index & $\begin{array}{l}\text { Germination } \\
\text { index }\end{array}$ & $\begin{array}{l}\text { Days to first } \\
\text { germination } \\
\text { 50\% } \\
\text { germination }\end{array}$ & $\begin{array}{l}\text { Germination } \\
\text { Vindex }\end{array}$ \\
\hline $\mathrm{T}_{\mathrm{o}}$ & $5.50 \mathrm{a}$ & $6.00 \mathrm{a}$ & $44.53 \mathrm{~d}$ & $11.09 \mathrm{c}$ & $6.5 \mathrm{a}$ & $6.5 \mathrm{a}$ & $46.53 \mathrm{~d}$ & $11.84 \mathrm{c}$ \\
\hline $\mathrm{T}_{1}$ & $5.00 \mathrm{bc}$ & $5.10 \mathrm{~b}$ & $46.09 \mathrm{c}$ & $11.79 \mathrm{bc}$ & $6.0 \mathrm{bc}$ & $5.6 \mathrm{~b}$ & $48.09 \mathrm{c}$ & $12.54 \mathrm{bc}$ \\
\hline $\mathrm{T}_{2}$ & $4.00 \mathrm{~d}$ & $4.25 \mathrm{c}$ & $56.33 \mathrm{a}$ & $14.06 \mathrm{a}$ & $5.0 \mathrm{~d}$ & $4.75 \mathrm{c}$ & $58.33 \mathrm{a}$ & $14.81 \mathrm{a}$ \\
\hline $\mathrm{T}_{3}$ & $4.50 \mathrm{~cd}$ & $4.75 \mathrm{~b}$ & $48.02 \mathrm{~b}$ & $12.13 \mathrm{~b}$ & $5.5 \mathrm{~cd}$ & $5.25 \mathrm{~b}$ & $50.02 \mathrm{~b}$ & $12.88 \mathrm{~b}$ \\
\hline $\mathrm{T}_{4}$ & $4.50 \mathrm{~cd}$ & $4.70 \mathrm{~b}$ & $48.90 \mathrm{~b}$ & $12.37 \mathrm{~b}$ & $5.5 \mathrm{~cd}$ & $5.2 \mathrm{~b}$ & $50.9 \mathrm{~b}$ & $13.12 \mathrm{~b}$ \\
\hline LSD (.05\%) & 0.73 & 0.42 & 0.86 & 0.57 & 0.72 & 0.41 & $0.85 \mathrm{~b}$ & 0.59 \\
\hline $\mathrm{CV}(\%)$ & 5.68 & 6.05 & 1.41 & 3.68 & 5.08 & 6.55 & 3.41 & 4.66 \\
\hline
\end{tabular}

Means followed by the same letter(s) did not differ significantly at $5 \%$ level by DMRT.

$\mathrm{T}_{\mathrm{o}}=$ Control

$\mathrm{T}_{1}=$ Horitoki leaf extract

$\mathrm{T}_{2}=$ Bohera leaf extract

$\mathrm{T}_{3}=$ Arjun leaf extract

$\mathrm{T}_{4}=$ Tulsi leaf extract 


\section{J. Environ. Sci. \& Natural Resources, 5(1): 141-150, 2012}

Table 2. Effects of some herbal plant leaf extract on shoot length of swamp cabbage and lady's finger seeds

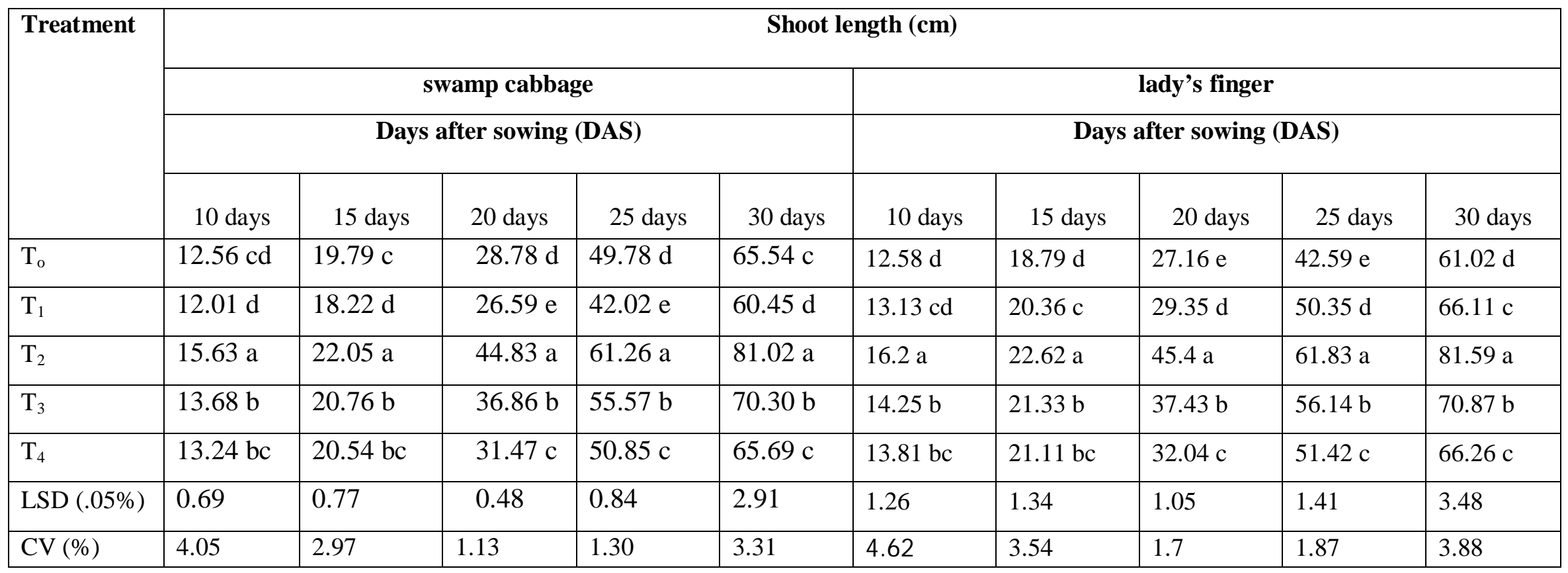

Means followed by the same letter(s) did not differ significantly at $5 \%$ level by DMRT. 


\section{Root length}

Root length of swamp cabbage seedling at different days after sowing was lowest at 10 days and showed an increasing trend up to 30 days (Table 3), At 10 days after sowing (DAS days) seed treated with Bohera showed the best result $(8.44 \mathrm{~cm})$ whereas Horitoki showed the lowest root length $(5.56 \mathrm{~cm})$. The highest root length of swamp cabbage seedling was found from $(11.46 \mathrm{~cm})$ at 15 days that was statistically different from others whereas the lowest root length $(8.66 \mathrm{~cm})$ was recorded with Horitoki leaf extract. The other treatments showed moderately similar results for the same days after sowing. At 20 days, 25 days and 30 days the highest root length was recorded in case of seed treated with Bohera $(16.78 \mathrm{~cm}, 21.14 \mathrm{~cm}$ and $27.82 \mathrm{~cm}$, respectively). The other treatments performed moderately. The increasing tendency of root length in aqueous extract of Arjun treated seedlings might be due to the presence of some growth regulator and the lowest root length of swamp cabbage seedling $(5.56 \mathrm{~cm})$ was obtained in seed treated with horitoki aqueous extract.(Table-3, graph-6) The highest root length of swamp cabbage seedling was found in seeds treated with bohera might be due to the presence of some growth regulator or other compounds present in the respective aqueous extract.

\section{Effect of aqueous extract of herbal leaves on ladys finger \\ Germination}

The highest germination (6.5) of seed was obtained in seed treated with water followed by seed treated with Horitoki leaf extract $\left(\mathrm{T}_{1}\right)$, Arjun leaf extract $\left(\mathrm{T}_{3}\right)$ and Tulsi leaf extract $\left(\mathrm{T}_{4}\right)$. Consequently, lowest germination (5.0) was recorded when seeds were treated with Bohera leaf extract $\left(\mathrm{T}_{2}\right)$ (Table 1).

\section{Shoot length}

Shoot length of ladys finger at different days after sowing influenced significantly by the effects of different leaf extract (Table 2). The highest shoot length $(16.2,22.62,45.4,61.83$ and 81.59) was obtained when seed was treated with Bohera leaf extract $\left(\mathrm{T}_{2}\right)$ at $10 \mathrm{DAS}, 15 \mathrm{DAS}, 20 \mathrm{DAS}, 25 \mathrm{DAS}$ and 30 DAS followed by seed treated with Arjun leaf extract $\left(\mathrm{T}_{3}\right)$ which is identical with the result where seed treated with Tulsi leaf extract $\left(\mathrm{T}_{4}\right)$. On the other hand, lowest shoot length $(12.58,18.79,27.16,42.59$ and 61.02) was obtained in seeds treated with water at 10 DAS, 15 DAS, 20 DAS, 25 DAS and 30 DAS.

\section{Root length}

Effect of leaf extract on root length of ladys finger varied significantly at different days after sowing (Table 3). The highest root $(8.74,17.08,21.44$ and 28.12) length was obtained when seed treated with Bohera leaf extract $\left(\mathrm{T}_{2}\right)$ at $10 \mathrm{DAS}, 20 \mathrm{DAS}, 25 \mathrm{DAS}$ and 30 DAS. But at 15 DAS the highest root length (11.76) was obtained when seed treated with Tulsi leaf extract $\left(\mathrm{T}_{4}\right)$. While the lowest root length $(5.86$, $8.96,10.52,12.78$ and 15.51) was recorded seed treated water.

\section{Chemical Investigation on Aqueous Extracts of Leaves of Herbal Plants}

The results in this experiment indicates that the aqueous extracts of different plant species have either promotive or inhibitory effects on germination parameters like time to get fast germination, time to get $50 \%$ germination, coefficient of germination, vigor index, germination index and final germination percentages and increasing on root and shoot length or early growth of vegetables. To find out this active compound Thin Layer Chromatography (TLC) of chloroform extract of Horitoki (Terminalia chebula) and ethanol extract of Bohera (Terminalia belirica) was done. The TLC of chloroform extract of Horitoki (Terminalia chebula) showed presence of four compounds at Hexane: Ethylacetate (5:1 v/v) Fig.1, this result suggested that it contained three distinct compounds, designated as $\mathrm{C}_{1}, \mathrm{C}_{2}$ and $\mathrm{C}_{3}$ respectively. The TLC (Thin Layer Chromatography) of ethanol extract of Bohera (Terminalia belirica) showed presence of four compounds at hexane: ethylacetate $(3: 1 \mathrm{v} / \mathrm{v})$ Fig. 2 . This result suggested that it contained four distinct compounds, designated as $\mathrm{P}_{1}, \mathrm{P}_{2}, \mathrm{P}_{3}$ and $\mathrm{P}_{4}$ respectively. Here the intensity of non-polar compound like $\mathrm{P}_{1}$ was too much high comparison with others. 
Table 3. Effects of some herbal plant leaf extract on root length length of swamp cabbage and lady's finger seeds

\begin{tabular}{|c|c|c|c|c|c|c|c|c|c|c|}
\hline \multirow[t]{3}{*}{ Treatment } & \multicolumn{10}{|c|}{ Root length (cm) } \\
\hline & \multicolumn{5}{|c|}{ Days after sowing (DAS) } & \multicolumn{5}{|c|}{ Days after sowing (DAS) } \\
\hline & 10 days & 15 days & 20 days & 25 days & 30 days & 10 days & 15 days & 20 days & 25 days & 30 days \\
\hline $\mathrm{T}_{\mathrm{o}}$ & $5.61 \mathrm{c}$ & $8.59 \mathrm{c}$ & $11.51 \mathrm{c}$ & $13.73 \mathrm{~d}$ & $16.52 \mathrm{~d}$ & $5.86 \mathrm{c}$ & $8.96 \mathrm{c}$ & $10.52 \mathrm{~d}$ & $12.78 \mathrm{e}$ & $15.51 \mathrm{e}$ \\
\hline $\mathrm{T}_{2}$ & $8.44 \mathrm{a}$ & $11.46 \mathrm{a}$ & $16.78 \mathrm{a}$ & $21.14 \mathrm{a}$ & $27.82 \mathrm{a}$ & $8.74 \mathrm{a}$ & $9.53 \mathrm{c}$ & $17.08 \mathrm{a}$ & $21.44 \mathrm{a}$ & $28.12 \mathrm{a}$ \\
\hline $\mathrm{T}_{3}$ & $7.29 \mathrm{~b}$ & $10.28 \mathrm{~b}$ & $13.29 \mathrm{~b}$ & $16.85 \mathrm{~b}$ & $20.56 \mathrm{~b}$ & $7.59 \mathrm{~b}$ & $10.58 \mathrm{~b}$ & $13.59 \mathrm{~b}$ & $17.15 \mathrm{~b}$ & $20.86 \mathrm{~b}$ \\
\hline $\mathrm{T}_{4}$ & $6.12 \mathrm{c}$ & $9.23 \mathrm{c}$ & $12.52 \mathrm{~b}$ & $15.66 \mathrm{c}$ & $18.78 \mathrm{c}$ & $6.42 \mathrm{c}$ & $11.76 \mathrm{a}$ & $12.82 \mathrm{~b}$ & $15.96 \mathrm{c}$ & $19.08 \mathrm{c}$ \\
\hline LSD $(.05 \%)$ & 0.59 & 0.76 & 0.91 & 0.85 & 0.86 & 0.89 & 1.06 & 1.21 & 1.15 & 1.16 \\
\hline
\end{tabular}

Means followed by the same letter(s) did not differ significantly at $5 \%$ level by DMRT. 
Table 4. $\mathrm{R}_{\mathrm{f}}$ values detected compounds of Horitoki (Terminalia chebula) with Chloroform solvent and Bohera (Terminalia belirica) with ethanol solvent

\begin{tabular}{|c|c|c|c|}
\hline Name of plant species & $\begin{array}{c}\text { Ratio of Hexane and } \\
\text { Ethylacetate }\end{array}$ & Detected components & $\mathrm{R}_{\mathrm{f}}$ value \\
\hline Horitoki & $5: 1$ & $\mathrm{C}_{1}$ & 0.94 \\
(Terminalia chebula) & $\mathrm{C}_{2}$ & 0.72 \\
& Ratio of Alcohol and & $\mathrm{C}_{3}$ & 0.45 \\
\hline & Ethylacetate & Detected components & $\mathrm{R}_{\mathrm{f}}$ value \\
\hline Bohera & $3: 1$ & $\mathrm{P}_{1}$ & 0.90 \\
& & $\mathrm{P}_{2}$ & 0.85 \\
(Terminalia belirica $)$ & $\mathrm{P}_{3}$ & 0.55 \\
& & $\mathrm{P}_{4}$ & 0.10 \\
\hline
\end{tabular}




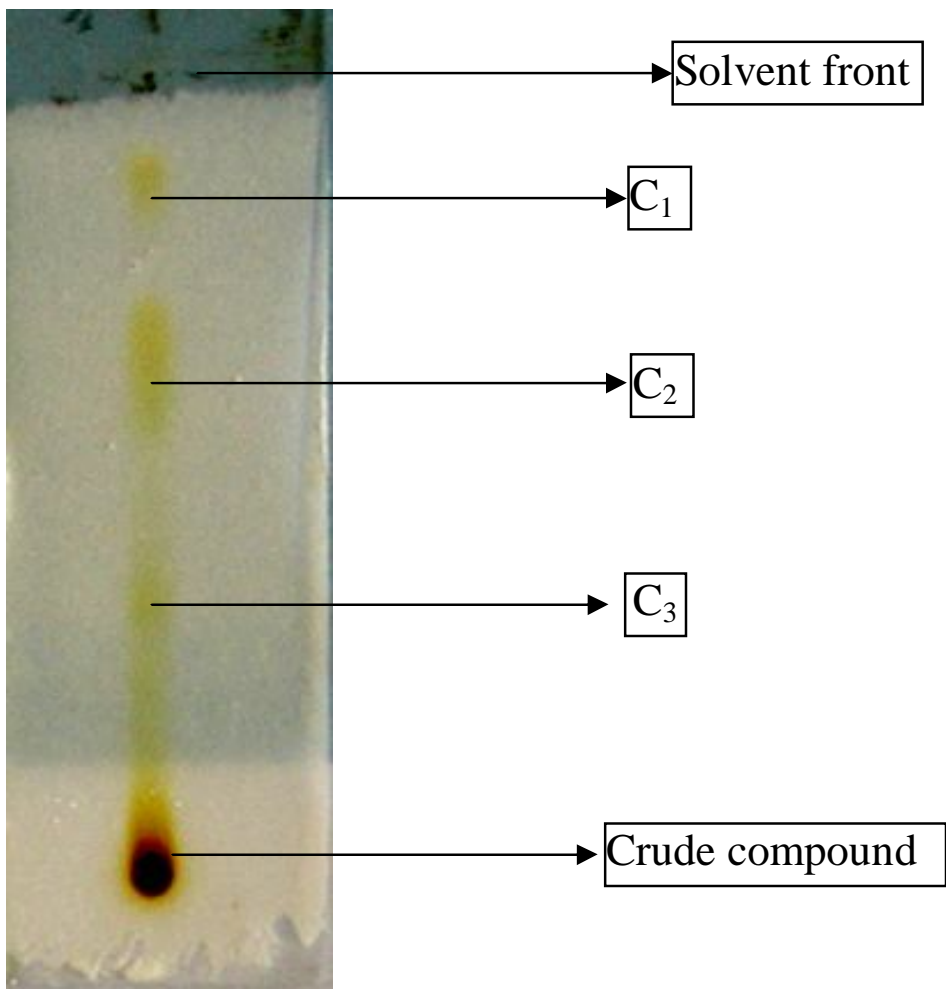

Fig. 1. Thin Layer Chromatographic Plate of Terminalia chebula (Horitoki)

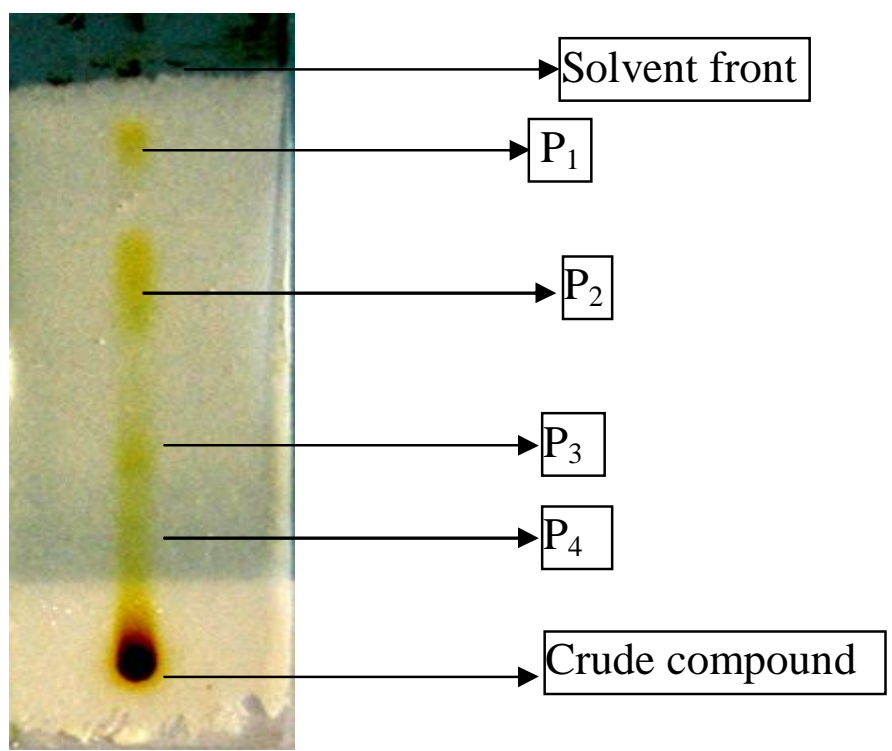

Fig. 2. Thin Layer Chromatographic Plate of Terminalia belerica (Bohera) 


\section{Conclusions}

This study interestingly indicated that herbal plant extracts have strong biological activity in the field of agriculture. From this small scale study we may conclude that;

i. Aqueous extract of bohera significantly enhance the germination of vegetable crops.

ii. It needs pot experiment as well as field experiment with bohera extract during cultivation of vegetable crops for final conclusion.

iii. Leaves of bohera may contain some growth promoting and other bio-active substances.

It needs isolation of active compounds from leaves of bohera extract and their structure determination by spectral study is also most essential

\section{Acknowledgements}

We are very grateful to the Department of Agricultural Chemistry and Department of Biochemistry and Molecular Biology, Hajee Mohammad Danesh Science and Technology University (HSTU), Dinajpur.

\section{References}

Guenzi, W.D. and Calla, T.M. Mc. 1962. Inhibition of germination and seedling development by crop residue. Soil Sci. Soc. Am. Proc. 26: 4556-4558.

Hong, Gao; Huang, Yi-Na; Xu Pei Yu and Kawabata, Jun. 2005. Division of Applied Bioscience, Graduate School of Agriculture, Hokkaido University, Kita-ku, Sapporo 060-8589, Japan.
Islam, M. S; Shahjahan, M; Motaleb, M. A; Alam, M. N. and Das, A. K. 2002. Repellent and antifeedent property of some indigenous plant extracts against granary weevil Sitophillus oryzae L. Bangladesh J. Environ. Sci. 8: 136-140.

Kohata, K; Yamauchi, Y; Ujihara, T. and Hprie, H. 2004. Growth Inhibitory Activity of Tea-Seed saponins and Glyphosate to Weed Seedlings. $J$. Janick (cd.), Alexandria, 38(4): 267-270.

Regnault-Roger, C; Hamraoui, A; Holeman, M. and Theron, E. and Pinel, R. 2005. Insecticidal effect of essential oils from mediterranean plants upon Acanthoscelides Obtectus, Coleoptera: Bruchidae, a pest of kidney bean, Phaseolus vulgaris. J. Chem. Ecol., 19(6).

Roy, B; Alam, M. R; Sarker, B. C; Rahman, M.S; Islam, M. J; Hakim, M. A. 2006. Effects of aqueous extracts of some weeds on germination and growth of wheat and jute seeds with emphasis on chemical investigation. J. Biol. Sci., 6(2): 412-416.

Singh, S. C. 2004. Effect of neem oil as surface protect ant of lentil seeds against the pulse beetle. Callosobruchus chinensis (Linn) (Coleoptera:Bruchidae). J. Appl. 2001. Res. 15(2): 226-228.

Tremeterra, P; Sciarretta, A; Adler, C; Navarro, S; Scholler, M. and Hansen, L. S. 2002. Activity of chilly, Capsicum annum L. var. acuminatum, on stored product insects Oryzaephilus surunamensis L., Sitophillus oryzae L. and Tribolim casteneum. Proceeding of the IOBCWPRS working group. Intigrated protection in stored products. 25(3): 177-182.

Tripathi, R.S. and Singh, R.S. 1981. Allelopathic potential of Eupatorium adnophorum a dominant rederal weed of Meghalya. Proceedings of the Indian National Science Academy. 47(3): 458462. 